\title{
Isolation and Characterization of a Lytic and Highly Specific Phage against Yersinia enterocolitica as a Novel Biocontrol Agent
}

\author{
Kyoung Min Gwak ${ }^{1}$, In Young Choi ${ }^{1}$, Jinyoung Lee ${ }^{2}$, Jun-Hyun $\mathrm{Oh}^{2}$, and Mi-Kyung Park ${ }^{1,3 *}$ \\ ${ }^{1}$ School of Food Science and Biotechnology, and ${ }^{3}$ Food and Bio-industry Research Institute, Kyungpook National University, Daegu 41566, \\ Republic of Korea \\ ${ }^{2}$ Department of Plant and Food Sciences, Sangmyung University, Cheonan 31066, Republic of Korea
}

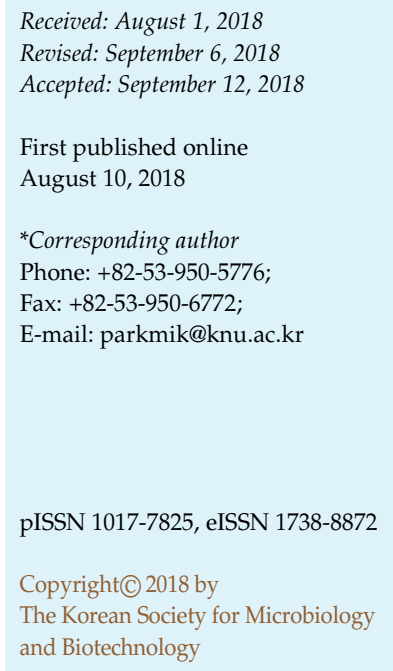

\begin{abstract}
The aim of this study was to isolate and characterize a lytic Yersinia enterocolitica-specific phage (KFS-YE) as a biocontrol agent. KFS-YE was isolated and purified with the final concentration of $(11.72 \pm 0.03) \log \mathrm{PFU} / \mathrm{ml}$ from poultry. As observed by transmission electron microscopy, KFS-YE consisted of an icosahedral head and a contractile tail, and was classified in the Myoviridae family. KFS-YE showed excellent narrow specificity against Y. enterocolitica only. Its lytic activity was stable at wide ranges of $\mathrm{pH}(4-11)$ and temperature $\left(4-50^{\circ} \mathrm{C}\right)$. The latent period and burst size of KFS-YE were determined to be $45 \mathrm{~min}$ and $38 \mathrm{PFU} /$ cell, respectively. KFS-YE showed relatively robust storage stability at $-20,4$, and $22^{\circ} \mathrm{C}$ for 40 weeks. KFS-YE demonstrated a bactericidal effect in vitro against $Y$. enterocolitica and provided excellent efficiency with a multiplicity of infection as low as 0.01 . This study demonstrated the excellent specificity, stability, and efficacy of KFS-YE as a novel biocontrol agent. KFS-YE may be employed as a practical and promising biocontrol agent against $Y$. enterocolitica in food.
\end{abstract}

Keywords: Bacteriophages (phages), Yersinia enterocolitica, biocontrol, lytic, storage

\section{Introduction}

Yersinia enterocolitica is a gram-negative, non-spore-forming, coccobacilli, psychrotrophic, and facultative anaerobe, which is one of three Yersinia species that are pathogenic to humans, along with $Y$. pestis, and Y. pseudotuberculosis [1, 2]. The most predominant natural hosts for $Y$. enterocolitica are animals (especially pigs). Y. enterocolitica also exists ubiquitously in water, soil, plant surfaces, and foods [3]. Although animals are the major source of $Y$. enterocolitica, many cases have recently been reported in which outbreaks of $Y$. enterocolitica were associated with fresh produce such as salad, bean sprouts and leafy vegetables $[4,5]$. Yersinia infection, commonly known as yersiniosis, begins with some common symptoms such as fever, diarrhea (often bloody), and abdominal pain, which is sometimes confused with appendicitis. It is also associated with some severe complications such as skin rash, meningitis, mesenteric lymphadenitis, and sepsis [2,3]. A European Union Summary Report [6] classified yersiniosis as the third most common zoonosis in Europe [4]. Moreover, recent findings revealed that Yersinia species had developed resistance against penicillin, ampicillin, cephalosporin, and macrolides due to the production of beta-lactamases [7]. Thus, a safe, ecofriendly and effective "green" approach is required to control Y. enterocolitica to ensure food safety and public health [8].

Bacteriophages (phages) are the most abundant entities $\left(10^{31}-10^{32}\right)$ in nature and have recently gathered more attention as green biocontrol agents owing to several advantages, including excellent target specificity, the ability to multiply in the presence of hosts, preparation and cost efficiencies, stability in wide-ranging $\mathrm{pH}$ levels and temperatures, and harmlessness to humans, animals, and plants [9-11]. The necessity of novel biocontrol agents has prompted us to isolate numerous phages (mainly lytic phages) from various environments and foods [12]. Unlike lysogenic phages, the lytic phage can lyse the target bacteria by integrating their DNA into the bacterial chromosome and then replicating themselves inside the host, a trait that is preferred for their use as biocontrol agents [2, 13, 14]. 
Table 1. Y. enterocolitica-specific phages reported in the literatures.

\begin{tabular}{|c|c|c|c|c|c|c|c|}
\hline \multirow{2}{*}{ Classification } & \multirow{2}{*}{ Name } & \multirow{2}{*}{ Sources } & \multicolumn{2}{|c|}{ Length (nm) } & \multirow{2}{*}{$\begin{array}{l}\text { Latent period } \\
\text { (min) }\end{array}$} & \multirow{2}{*}{$\begin{array}{l}\text { Burst size } \\
\text { (PFU/cell) }\end{array}$} & \multirow{2}{*}{ References } \\
\hline & & & Head & Tail & & & \\
\hline \multirow[t]{7}{*}{ Myoviridae } & KFS-YE & Poultry & 118 & 126 & 45 & 38 & Present study \\
\hline & 8/C239 & Human feces & 58 & 140 & - & - & [39] \\
\hline & PY100 & Pig manure & 70 & 80 & 30 & 120 & [40] \\
\hline & PY95 & Y. enterocolitica* & - & - & - & - & [19] \\
\hline & PY68 & Y. enterocolitica* & - & - & - & - & [19] \\
\hline & PY44 & Y. enterocolitica* & - & - & - & - & [19] \\
\hline & PY20 & Y. enterocolitica* & - & - & - & - & [19] \\
\hline \multirow[t]{4}{*}{ Podoviridae } & ФYeO3-12 & Sewage & 57 & 15 & 25 & 120 & [1] \\
\hline & AP5 & Sewage & 55 & 12 & - & - & [41] \\
\hline & PY96 & Y. enterocolitica* & - & - & - & - & [19] \\
\hline & PY31 & Y. enterocolitica* & - & - & - & - & [19] \\
\hline \multirow[t]{2}{*}{ Siphoviridae } & PY30 & Y. enterocolitica* & - & - & - & - & [19] \\
\hline & PY54 & Y. enterocolitica* & - & - & - & - & [19] \\
\hline- & fPS- $8,11,16,27,67$ & Pig stools & - & - & - & - & [2] \\
\hline
\end{tabular}

Asterisk $\left(^{*}\right)$ means that $Y$. enterocolitica-specific phage was isolated from Yersinia strains by mitomycin C induction.

Although numerous phages have been isolated and even employed in various foods as biocontrol agents in previously published reports, the focus of these efforts was limited to Salmonella-, Escherichia coli- and Listeria-specific phages [12, 15-17]. Moreover, a few published reports are available today regarding Yersinia-specific phages as shown in Table 1, but these previous studies were primarily focused on isolation only rather than characterization and subsequent employment of phages as biocontrol agents in foods $[1,18,19]$. In addition, the FDA has recently permitted phages to be used as "food additives" with a Generally Recognized as Safe (GRAS) designation [17]. Therefore, a lot of phage research has been focused on the investigation of new phages as biocontrol agents. To investigate for an applicable and practical $Y$. enterocolitica-specific phage as a biocontrol agent, the phage first needs to be isolated and purified. The properties of a purified phage also need to be characterized for use in food since it could be affected by several environmental factors, such as $\mathrm{pH}$, temperature, storage period, and chemicals [12, 20,21]. Therefore, as an initial study, a lytic $Y$. enterocolitica-specific phage was isolated, purified, and characterized to demonstrate its potential as a novel biocontrol agent.

\section{Materials and Methods}

\section{Bacterial Strains, Culture Media, and Growth Condition}

Each bacterial strain listed in Table 2 was grown in $25 \mathrm{ml}$ of tryptic soy broth (TSB, Difco, Sparks, USA) for $16 \mathrm{~h}$ at $37^{\circ} \mathrm{C}$ with constant shaking at $110 \mathrm{rpm}$. After washing three times with sterilized phosphate-buffered saline (PBS, pH 7.4, Life Technologies Co., UK) by centrifugation at $4,000 \times g$ for $10 \mathrm{~min}$ at $4^{\circ} \mathrm{C}$, the collected bacteria were suspended in PBS. The concentration of each bacterial suspension was adjusted to $8 \log \mathrm{CFU} / \mathrm{ml}$ using a pre-constructed standard curve determined by optical density at $640 \mathrm{~nm}$.

\section{Isolation, Propagation, and Purification of Phages from Washing} Water Used for Poultry and Carcasses

One liter of wash water was collected from each processing step in a poultry plant (Orpum Ltd., Sangju) and five slaughterhouses (Yeongcheon, Gumi, Gunwi, Daegu, and Andong) in Korea. Twenty-five milliliters of the water was mixed with $225 \mathrm{ml}$ of TSB containing $1 \mathrm{ml}$ of $Y$. enterocolitica ATCC 23715 as an indicator strain. After incubating for $16 \mathrm{~h}$ at $37^{\circ} \mathrm{C}$ with 160 -rpm agitation, the mixture was centrifuged at $4,000 \times g$ for $10 \mathrm{~min}$ at $4^{\circ} \mathrm{C}$. The supernatant was filtered using a $0.20-\mu \mathrm{m}$ cellulose acetate filter (Advantec Toyo Ltd., Kaisha, Japan) and dot assay was then performed. Ten microliters of filtrate was spotted on the surface of TA soft agar (4 g/l agar, $8 \mathrm{~g} / 1$ nutrient broth, $5 \mathrm{~g} / 1 \mathrm{NaCl}, 0.2 \mathrm{~g} / 1$ $\mathrm{MgSO}_{4}, 0.05 \mathrm{~g} / 1 \mathrm{MnSO}_{4}$, and $0.15 \mathrm{~g} / 1 \mathrm{CaCl}_{2}$ ) that was previously solidified with $200 \mu \mathrm{l}$ of an overnight culture of $Y$. enterocolitica ATCC 23715. After incubation for $16 \mathrm{~h}$ at $37^{\circ} \mathrm{C}$, the formation of plaque and its size were measured for further procedures.

For the isolation of a single phage against $Y$. enterocolitica ATCC 23715, $100 \mu$ f filtrate with 10-fold serial dilutions and $200 \mu \mathrm{l}$ of an overnight culture of $Y$. enterocolitica ATCC 23715 were mixed into $4 \mathrm{ml}$ of TA soft agar. After mixing and pouring onto a tryptic soy agar (TSA, Difco Laboratories Inc., Sparks, USA) plate (plaque assay), it was incubated for $16 \mathrm{~h}$ at $37^{\circ} \mathrm{C}$. A single plaque was then 
Table 2. Specificity of KFS-YE.

\begin{tabular}{|c|c|c|}
\hline Bacteria & $\begin{array}{c}\text { Plaque } \\
\text { turbidity* }\end{array}$ & $\begin{array}{c}\text { Plaque } \\
\text { size }(\mathrm{cm})\end{array}$ \\
\hline Yersinia enterocolitica ATCC 23715 & ++ & $1.27 \pm 0.05^{a}$ \\
\hline Y. enterocolitica ATCC 55075 & + & $0.95 \pm 0.06^{b}$ \\
\hline Y.enterocolitica ATCC 9610 & + & $0.79 \pm 0.06^{b}$ \\
\hline Y.pseudotuberculosis ATCC 29833 & - & - \\
\hline Y. ruckeri ATCC 29473 & - & - \\
\hline Y. tuberculosis & - & - \\
\hline Y. frederiksenii & - & - \\
\hline Aeromonas hydrophila ATCC 7966 & - & - \\
\hline A. veronii АTCC 9071 & - & - \\
\hline A. salmonicida ATCC 33658 & - & - \\
\hline A. media ATCC 33907 & - & - \\
\hline A. sobria ATCC 43979 & - & - \\
\hline Bacillus cereus ATCC 21768 & - & - \\
\hline B. cereus ATCC 13061 & - & - \\
\hline B. subtilis ATCC 6633 & - & - \\
\hline Campylobacter jejuni & - & - \\
\hline Escherichia coli ATCC 15144 & - & - \\
\hline E. coli ATCC BAA-2196 & - & - \\
\hline E. coli O157:H7 ATCC 43895 & - & - \\
\hline Klebsiella pneumoniae ATCC 13883 & - & - \\
\hline Listeria monocytogenes ATCC 19116 & - & - \\
\hline L. monocytogenes ATCC 7644 & - & - \\
\hline L. innocua ATCC 33090 & - & - \\
\hline Pseudomonas aeruginosa ATCC 9027 & - & - \\
\hline P. aeruginosa ATCC 10145 & - & - \\
\hline Salmonella Enteritidis ATCC 13076 & - & - \\
\hline S. Dublin & - & - \\
\hline S. Hartford & - & - \\
\hline S. Heidelberg & - & - \\
\hline S. Mission & - & - \\
\hline S. Montevideo & - & - \\
\hline S. Newport & - & - \\
\hline S. Panama & - & - \\
\hline S. Salamae & - & - \\
\hline S. Senftenberg & - & - \\
\hline S. Typhi & - & - \\
\hline S. Typhimurium ATCC 19586 & - & - \\
\hline S. Typhimurium ATCC 15812 & - & - \\
\hline Shigella flexneri $2457 \mathrm{~T}$ & - & - \\
\hline S. sonnei ATCC 9290 & - & - \\
\hline Staphylococcus aureus ATCC 25923 & - & - \\
\hline Vibrio parahaemolyticus ATCC 17802 & - & - \\
\hline V. vulnificus & - & - \\
\hline
\end{tabular}

${ }^{*}++$, clear plaque; + , turbid plaque; -, no plaque.

Different letters ( $\mathrm{a}$ and $\mathrm{b}$ ) represent significant differences at $p<0.05$.

All bacterial strains with ATCC number and without ATCC number were provided from the American Type of Culture Collection and the laboratory in the Department of Plant and Food Sciences at Sangmyung University in Korea, respectively, except for Yersinia tuberculosis and Yersinia frederiksenii.

Yersinia tuberculosis and Yersinia frederiksenii were provided from the Korea Veterinary Culture Collection (KVCC) and Korea Centers for Disease Control and Prevention (KCDC), respectively. eluted with sodium chloride-magnesium sulfate (SM) buffer (50 mmol/l Tris-HCl, $100 \mathrm{mmol} / \mathrm{l} \mathrm{NaCl}, 10 \mathrm{mmol} / 1 \mathrm{MgSO}_{4}, \mathrm{pH}$ 7.5) with vigorous agitation for $1 \mathrm{~h}$ at $22^{\circ} \mathrm{C}$ (plaque assay). For the propagation of the phage, $1 \%$ of the overnight culture of Y. enterocolitica ATCC 23715 was mixed with $3 \mathrm{ml}$ of TA broth and incubated for $2 \mathrm{~h}$ at $37^{\circ} \mathrm{C}$ prior to adding $1 \mathrm{ml}$ of the eluted single phage. After incubation for $2 \mathrm{~h}$ at $37^{\circ} \mathrm{C}$, the mixture was centrifuged at 2,400 $\times g$ for $10 \mathrm{~min}$ at $4^{\circ} \mathrm{C}$ and the supernatant was filtered through the $0.20 \mu \mathrm{m}$ cellulose acetate filter. The above procedures were performed several times with increasing amounts of TA broth to increase the phage concentration. The final filtrate was precipitated using 10\% polyethylene glycol (PEG) 6000 (SigmaAldrich, USA) and $10 \mathrm{ml}$ of $1 \mathrm{~mol} / 1 \mathrm{NaCl}$. After precipitation, the PEG-precipitated filtrate was centrifuged at 7,200 $\times g$ for $20 \mathrm{~min}$ at $4^{\circ} \mathrm{C}$. The pellet was suspended in the SM buffer and subjected to $\mathrm{CsCl}$ gradient ultracentrifugation at $39,000 \times g$ for $2 \mathrm{~h}$ at $4^{\circ} \mathrm{C}$. Finally, a bluish opalescent layer was dialyzed and stored in SM buffer, and the concentration of the purified phage (referred to as KFS-YE hereafter) was determined using plaque assay.

\section{Morphological Analysis of KFS-YE}

Ten microliters of KFS-YE (11 log PFU/ml) was placed on the top of a carbon-coated copper grid and stained with $2 \%$ phosphotungstic acid (Sigma-Aldrich Co., USA). The stained KFSYE was observed using a transmission electron microscopy (TEM) (H-7100, Hitachi Ltd., Chiyoda, Japan) at $100 \mathrm{kV}$ with 50,000 $\times$ to $200,000 \times$ magnifications.

\section{Specificity of KFS-YE}

The specificity of KFS-YE was investigated by employing each overnight culture of bacteria $(8 \log \mathrm{CFU} / \mathrm{ml})$, and a dot assay was performed following the procedures described for the methods of isolation, propagation, and purification of phages.

Effects of pHs, Temperatures, and Storage Conditions on the Stability of KFS-YE

The lytic activity of KFS-YE was investigated by exposing it to various $\mathrm{pH}$ levels and temperatures. To determine the $\mathrm{pH}$ effect on the lytic activity of KFS-YE, $100 \mu$ of KFS-YE (9 log PFU/ml) was mixed with $900 \mu \mathrm{l}$ of TSB at different $\mathrm{pH}$ levels (2-12) and incubated at $22^{\circ} \mathrm{C}$ for $1 \mathrm{~h}$. To determine the temperature effect, $100 \mu \mathrm{l}$ of KFS-YE $(9 \log \mathrm{PFU} / \mathrm{ml})$ was mixed with $900 \mu \mathrm{l}$ of SM buffer ( $\mathrm{pH} \mathrm{7}$ ) and incubated at various temperatures $\left(4^{\circ} \mathrm{C}, 22^{\circ} \mathrm{C}\right.$, $37^{\circ} \mathrm{C}, 50^{\circ} \mathrm{C}, 60^{\circ} \mathrm{C}, 70^{\circ} \mathrm{C}$, and $80^{\circ} \mathrm{C}$ ) for $1 \mathrm{~h}$. Finally, the plaque assay was performed for comparisons following the procedures described for the methods of isolation, propagation, and purification of phages. In addition, KFS-YE $(9 \log \mathrm{PFU} / \mathrm{ml})$ in TA broth was stored at various temperatures $\left(-80^{\circ} \mathrm{C},-20^{\circ} \mathrm{C}, 4^{\circ} \mathrm{C}\right.$, and $\left.22^{\circ} \mathrm{C}\right)$ to determine its stability during the storage period. To minimize damage from freezing, $20 \%$ glycerol was added to KFS-YE stored in TA broth at $-80^{\circ} \mathrm{C}$ and $-20^{\circ} \mathrm{C}$. At 2-week intervals, the plaque assay was performed to measure the lytic activity of KFS-YE over the storage periods. 


\section{One-Step Growth Curve of KFS-YE}

Equivalent ratios of overnight cultures of $Y$. enterocolitica ATCC $23715(8 \log \mathrm{CFU} / \mathrm{ml})$ and KFS-YE $(8 \log \mathrm{PFU} / \mathrm{ml})$ were mixed and adsorbed for $15 \mathrm{~min}$ at $22^{\circ} \mathrm{C}$. After centrifugation at $11,400 \times g$ for $10 \mathrm{~min}$ at $4^{\circ} \mathrm{C}$, a pellet containing infected bacteria was resuspended in $10-\mathrm{ml}$ TSB prior to incubation at $37^{\circ} \mathrm{C}$. At $5 \mathrm{~min}$ intervals, the plaque assay was performed to determine the latent period, rise period, and burst size of KFS-YE.

\section{Bactericidal Effect of KFS-YE against Y. enterocolitica}

Two percent of an overnight culture of $Y$. enterocolitica ATCC 23715 was inoculated into $50 \mathrm{ml}$ of TSB and incubated at $37^{\circ} \mathrm{C}$ with agitation until it reached the early exponential growth phase (approximately, $8 \log \mathrm{CFU} / \mathrm{ml}$ ). KFS-YE was added to the bacterial suspension in TSB to reach a multiplicity of infection (MOI) of $0.01,0.1,1.0$, and 10, respectively, for incubation during $20 \mathrm{~h}$ at $37^{\circ} \mathrm{C}$. A negative control was incubated without KFS-YE. The viable bacterial number was measured at $1 \mathrm{~h}$ intervals using a TSA plate.

\section{Statistical Analysis}

The experiments were replicated three times and the experimental results are expressed as means \pm standard deviations (SD). Student's paired $t$-test for two groups and a one-way analysis of variance (ANOVA) for more than two groups were used to compare the means using the GraphPad and InStatV.3 programs (GraphPad, USA). The significance level was determined at $p<0.05, p<0.01$ or $p<0.001$.

\section{Results}

\section{Isolation and Purification of KFS-YE}

Twelve phages were isolated from 20 water samples collected from a poultry plant and five slaughterhouses by using Y. enterocolitica ATCC 23715 as an indicator strain. Among the 12 phages, one $Y$. enterocolitica-specific phage was selected for further purification procedures because of its production of the largest $(1.25 \pm 0.06 \mathrm{~cm})$ and clearest plaque formation, which indicated relatively excellent lytic activity of the isolated phage among the others [22]. After propagation and purification of the Y. enterocolitica-specific phage, its final concentration was determined to be (11.72 \pm 0.03) $\log \mathrm{PFU} / \mathrm{ml}$, and it was named KFS-YE following the recommendation of Ackermann et al. [23].

\section{Morphological Characteristics of KFS-YE}

TEM images (Fig. 1) showed that KFS-YE consisted of an icosahedral head with a hexagonal image and a tail. The head length, head width, and tail length of KFS-YE were $118.4 \pm 11.6 \mathrm{~nm}, 102.4 \pm 6.1 \mathrm{~nm}$, and $125.7 \pm 15.8 \mathrm{~nm}$, respectively. The head and tail were connected by a neck

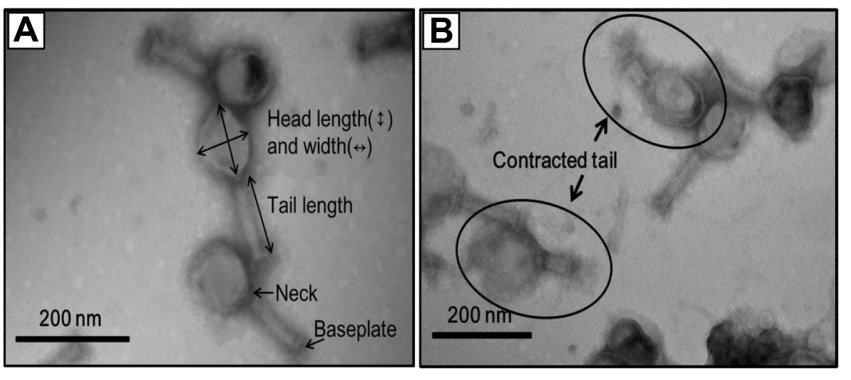

Fig. 1. TEM images of KFS-YE negatively stained with $2 \%$ phosphotungstic acid. The scale bars indicate $200 \mathrm{~nm}$.

(10.6 $\pm 0.5 \mathrm{~nm}$ in length), and a baseplate was also observed at one end of the tail (Fig. 1A). Conversely, the other TEM image (Fig. 1B) showed a relatively short tail length of $48.2 \pm 4.6 \mathrm{~nm}$, which indicated the contractility of KFS-YE. Thus, KFS-YE was classified into the Myoviridae family because it possessed an icosahedral head and contractile tail unlike the Podoviridae, and Siphoviridae families [22, 24].

\section{Specificity of KFS-YE}

KFS-YE showed clear plaques against $Y$. enterocolitica ATCC 23715, Y. enterocolitica ATCC 55075, and Y. enterocolitica ATCC 9610 whereas it did not demonstrate any plaques against Y. pseudotuberculosis ATCC 29833, Y. ruckeri ATCC 29473, Y. tuberculosis, or Y. frederiksenii (Table 2). In addition, the plaque produced by $Y$. enterocolitica ATCC 23715 was significantly larger and clearer than those of $Y$. enterocolitica ATCC 55075 and Y. enterocolitica ATCC $9610(p<0.05)$. More importantly, KFS-YE did not show any cross-genus and cross-species specificities against 43 other bacteria. Thus, KFS-YE demonstrated a highly narrow specificity against Y.enterocolitica only.

\section{Effects of pH Levels and Temperatures on the Stability of KFS-YE}

As an effective biocontrol agent, KFS-YE should be stable when exposed to various $\mathrm{pH}$ levels and temperatures [12] (Fig. 3). KFS-YE was stable at wide pH ranges of 4-11 and there were no significant reductions in the phage titer $(p>0.05)$. However, the concentration of the phage decreased significantly to $6.4 \pm 0.2 \log \mathrm{PFU} / \mathrm{ml}$ at $\mathrm{pH} 3$, and no plaques were observed at both pH 2 and 12 (Fig. 3A) $(p<0.05)$. Regarding the effect of temperature, the stability of KFS-YE was sustained at temperatures between $4^{\circ} \mathrm{C}$ and $50^{\circ} \mathrm{C}$ (Fig. 3B). Contrarily, the phage concentration decreased significantly to $5.2 \pm 0.3 \log \mathrm{PFU} / \mathrm{ml}$ and $2.7 \pm 0.1 \log \mathrm{PFU} / \mathrm{ml}$ at $60^{\circ} \mathrm{C}$ and $70^{\circ} \mathrm{C}$, respectively $(p<0.05)$. At more extreme temperatures $\left(e . g ., 80^{\circ} \mathrm{C}\right)$, phage stability was essentially lost. 
Table 3. Stability of KFS-YE stored at various temperatures for 40 weeks.

\begin{tabular}{|c|c|c|c|c|}
\hline \multirow{2}{*}{$\begin{array}{l}\text { Storage } \\
\text { periods } \\
\text { (weeks) }\end{array}$} & \multicolumn{4}{|c|}{ Storage temperatures $\left({ }^{\circ} \mathrm{C}\right)$} \\
\hline & -80 & -20 & 4 & 22 \\
\hline 0 & $8.41 \pm 0.02^{\text {ax }}$ & $8.41 \pm 0.02^{a x}$ & $8.41 \pm 0.02^{a x}$ & $8.41 \pm 0.02^{\text {ax }}$ \\
\hline 2 & $7.76 \pm 0.05^{\text {by }}$ & $8.39 \pm 0.01^{\mathrm{ax}}$ & $8.40 \pm 0.02^{a x}$ & $8.40 \pm 0.01^{\mathrm{ax}}$ \\
\hline 4 & $7.78 \pm 0.10^{\text {by }}$ & $8.38 \pm 0.03^{\text {ax }}$ & $8.36 \pm 0.09^{\mathrm{ax}}$ & $8.36 \pm 0.06^{\mathrm{a}}$ \\
\hline 6 & $7.77 \pm 0.15^{\text {by }}$ & $8.36 \pm 0.05^{\mathrm{ax}}$ & $8.37 \pm 0.04^{\mathrm{ax}}$ & $8.37 \pm 0.04$ \\
\hline 8 & $7.75 \pm 0.09^{\text {by }}$ & $8.37 \pm 0.04^{\text {ax }}$ & $8.37 \pm 0.05^{a x}$ & $8.37 \pm 0.02$ \\
\hline 10 & $7.73 \pm 0.06^{\text {by }}$ & $8.37 \pm 0.02^{a x}$ & $8.38 \pm 0.03^{\mathrm{ax}}$ & $8.38 \pm 0.04$ \\
\hline 12 & $7.75 \pm 0.05^{\mathrm{bz}}$ & $8.37 \pm 0.04^{\mathrm{ax}}$ & $8.39 \pm 0.04^{\text {ax }}$ & $8.39 \pm 0.06^{b}$ \\
\hline 14 & $7.75 \pm 0.05^{\mathrm{bz}}$ & $8.37 \pm 0.04{ }^{\mathrm{ax}}$ & $8.39 \pm 0.02^{\text {ax }}$ & $8.39 \pm 0.05^{\text {by }}$ \\
\hline 16 & $7.74 \pm 0.09^{\mathrm{bz}}$ & $8.38 \pm 0.02^{\mathrm{ax}}$ & $8.37 \pm 0.07^{\mathrm{ax}}$ & $8.37 \pm 0.03^{\text {by }}$ \\
\hline 18 & $7.75 \pm 0.02^{\mathrm{bz}}$ & $8.37 \pm 0.04^{\text {ax }}$ & $8.38 \pm 0.05^{\mathrm{ax}}$ & $8.38 \pm 0.03^{\text {by }}$ \\
\hline 20 & $7.52 \pm 0.02^{b z}$ & $8.25 \pm 0.07^{\mathrm{bx}}$ & $8.22 \pm 0.02^{b x}$ & $8.22 \pm 0.03^{\text {by }}$ \\
\hline 22 & $7.52 \pm 0.03^{\mathrm{cz}}$ & $8.25 \pm 0.05^{b x}$ & $8.24 \pm 0.01^{b x}$ & $8.24 \pm 0.01$ \\
\hline 24 & $7.51 \pm 0.01^{\mathrm{cz}}$ & $8.26 \pm 0.06^{b x}$ & $8.22 \pm 0.02^{b x}$ & $8.22 \pm 0.12$ \\
\hline 26 & $7.51 \pm 0.12^{\mathrm{cz}}$ & $8.26 \pm 0.06^{b x}$ & $8.19 \pm 0.08^{b x}$ & $8.19 \pm 0.13^{c}$ \\
\hline 28 & $7.52 \pm 0.03^{c z}$ & $8.23 \pm 0.02^{b x}$ & $8.22 \pm 0.03^{b x}$ & $8.22 \pm 0.09^{\text {cy }}$ \\
\hline 30 & $7.50 \pm 0.17^{\mathrm{cz}}$ & $8.21 \pm 0.09^{b x}$ & $8.24 \pm 0.05^{b x}$ & $8.24 \pm 0.06^{\text {cy }}$ \\
\hline 32 & $7.51 \pm 0.17^{\mathrm{cz}}$ & $8.26 \pm 0.02^{b x}$ & $8.24 \pm 0.03^{b x}$ & $8.24 \pm 0.15^{c y}$ \\
\hline 36 & $7.45 \pm 0.05^{\mathrm{cz}}$ & $8.26 \pm 0.06^{b x}$ & $8.23 \pm 0.04^{\mathrm{bx}}$ & $8.23 \pm 0.04^{\mathrm{cy}}$ \\
\hline 40 & $7.30 \pm 0.10^{\mathrm{d} z}$ & $8.08 \pm 0.13^{b x}$ & $8.19 \pm 0.11^{\mathrm{cx}}$ & $7.87 \pm 0.15^{d y}$ \\
\hline
\end{tabular}

Different letters $(a, b, c$, and $d)$ in columns and $(x, y$, and $z)$ in rows represent significant differences at $p<0.05$

\section{Effects of Storage Conditions on the Stability of KFS-YE}

Since previous studies $[25,26]$ have reported that a freezedrying method was very damaging to most Myoviridae phages, KFS-YE was stored at freezing temperatures $\left(-80^{\circ} \mathrm{C}\right.$ and $\left.-20^{\circ} \mathrm{C}\right)$, refrigerator temperature $\left(4^{\circ} \mathrm{C}\right)$, and room temperature $\left(22^{\circ} \mathrm{C}\right)$ in this study. As shown in Table 3, phage titer declined slightly with time at all storage conditions. There were significant declines observed in phage titer beginning at 12 weeks, 20 weeks, and 20 weeks when stored at $22^{\circ} \mathrm{C}, 4^{\circ} \mathrm{C}$, and $-20^{\circ} \mathrm{C}$, respectively $(p<0.05)$. However, there were no significant differences in phage titer when stored at $-20^{\circ} \mathrm{C}$ and $4^{\circ} \mathrm{C}$, except at 40 weeks $(p>0.05)$. Overall, phage titer was sustained with concentrations of $7.30 \pm 0.10 \mathrm{log} \mathrm{PFU} / \mathrm{ml}(87 \%), 8.08 \pm$ $0.13 \log \mathrm{PFU} / \mathrm{ml}(96 \%), 8.19 \pm 0.11 \log \mathrm{PFU} / \mathrm{ml}(97 \%)$, and $7.87 \pm 0.15 \log \mathrm{PFU} / \mathrm{ml}(94 \%)$ when stored at $-80^{\circ} \mathrm{C},-20^{\circ} \mathrm{C}$, $4^{\circ} \mathrm{C}$, and $22^{\circ} \mathrm{C}$, respectively, for 40 weeks. Interestingly, phage titer stored at $-80^{\circ} \mathrm{C}$ was significantly lower than those stored at other temperature conditions after the first 2 weeks $(p<0.05)$. In summary, KFS-YE showed a relatively robust stability when stored at $-20^{\circ} \mathrm{C}, 4^{\circ} \mathrm{C}$, and $22^{\circ} \mathrm{C}$ rather than at $-80^{\circ} \mathrm{C}$ for 40 weeks.

\section{One-Step Growth Curve of KFS-YE}

To elucidate the ability of KFS-YE to lyse Y. enterocolitica, the latent period and burst size were determined using a one-step growth curve analysis (Fig. 3). Because the definition of latent period is the time interval between the adsorption and the beginning of the first burst [27], it was determined to be $45 \mathrm{~min}$. After the latent period, the number of liberated phages increased significantly for $65 \mathrm{~min}$ in what is called the rise period $(p<0.05)$. Afterwards, the number of liberated phages were sustained for $25 \mathrm{~min}$ during the entire plateau period. Since the burst size was determined as the ratio of the mean yield of phages that infected the bacteria cells to the mean phage particles liberated [28], the burst size of KFS-YE was determined to be $38 \mathrm{PFU} /$ cell.

\section{Bactericidal Effect of KFS-YE against Y. enterocolitica}

The lytic property of KFS-YE at various concentrations was investigated for $20 \mathrm{~h}$ by the analysis of a bacterial growth curve pattern after KFS-YE infection (Fig. 4). The bacterial number of the control group (without introduction of phage) continued to increase during the entire incubation period, finally reaching $10.43 \pm 0.32 \log \mathrm{CFU} / \mathrm{ml}$. In contrast, infection with KFS-YE inhibited bacterial growth significantly at all MOIs for $20 \mathrm{~h}$ in comparison to that of the control group at each incubation time $(p<0.05)$. After the number of $Y$. enterocolitica decreased abruptly and significantly at all MOI values at $2 \mathrm{~h}$, the bacterial number was sustained up to $7 \mathrm{~h}(p<0.05)$. Although there were significant differences in the bacterial numbers starting at $17 \mathrm{~h}$ between MOI of 10 and other MOIs $(p<0.05)$, there were no obvious and significant differences observed among different dosages at the MOI values. Therefore, KFS-YE was able to inhibit Y. enterocolitica efficiently and significantly even at the lowest MOI of 0.01 .

\section{Discussion}

KFS-YE (Y.enterocolitica-specific phage) was isolated and purified among 12 phages and classified into the Myoviridae family because of its icosahedral head with contractile tail (Fig. 1) [22, 24]. To our knowledge, 12 Yersinia-specific phages, except those from the study of Salem et al. [2], have been reported and morphologically classified with six in Myoviridae, four in Podoviridae, and two in Siphoviridae (Table 1). Compared with these reported phages, the head 

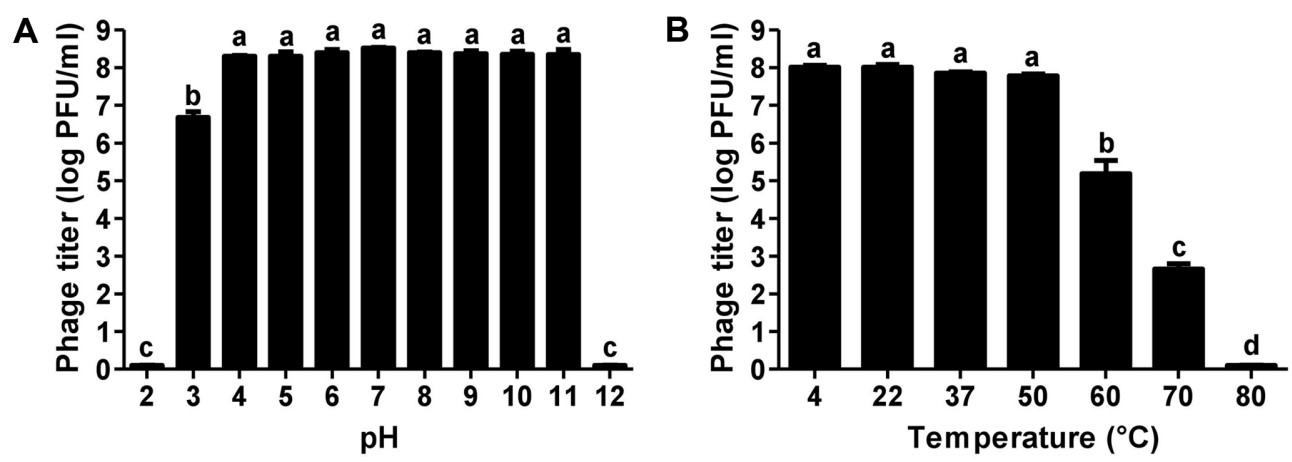

Fig. 2. Stability of KFS-YE at various (A) pHs and (B) temperatures. Different letters $(\mathrm{a}, \mathrm{b}, \mathrm{c}$, and $\mathrm{d})$ represent significant differences at $p<0.05(n=3)$.

length of KFS-YE was the longest, followed by that of the PY100 phage, and its tail length was second longest after that of the 8/C239 phage. Taken together, KFS-YE was assumed to be a novel Myoviridae phage against Yersinia because of the morphological differences in the length of head and tail. Thus, the morphological analysis supported the potential novelty of the isolated and purified KFS-YE.

The specificity of a phage is one of the most important factors determining its potential as a biocontrol agent [12, 29] (Table 2). KFS-YE demonstrated a highly narrow specificity against $Y$. enterocolitica only because it did not demonstrate any cross-genus and cross-species specificities against 43 other bacteria. Popp et al. [19] reported narrow host specificity for the PY44 phage and the PY96 phage against only Y. enterocolitica and Y. frederiksenii, respectively, among six Yersinia strains. Pajunen et al. [1] investigated the specificity of the $\Phi \mathrm{YeO} 3-12$ phage, indicating its narrow specificity against Y. enterocolitica, Y. frederiksenii, and

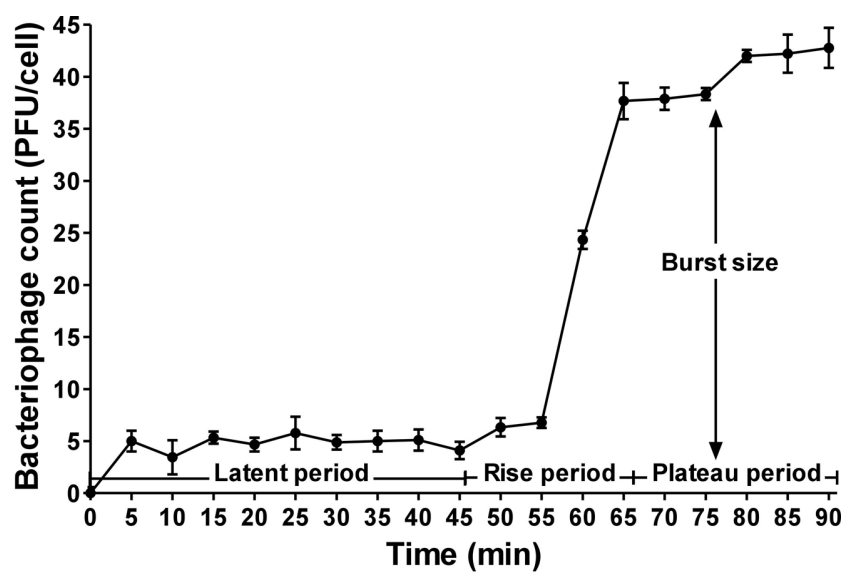

Fig. 3. One-step growth curve analysis of KFS-YE on Y. enterocolitica incubated in tryptic soy broth (TSB) at $37^{\circ} \mathrm{C}$ with gentle agitation.
Y. mollaretii among eight Yersinia strains. However, these two studies had a limitation because of the use of only Yersinia strains, and so their specificities against other genera were unclear. Conversely, Stevenson et al. [18] demonstrated that the YerA41 phage had a broad specificity against 9 bacterial strains, including E. coli, Enterobacter cloacae, Erwinia herbicola, Klebsiella pneumoniae, Y. ruckeri, and 4 strains of $Y$. enterocolitica. Taken together, the present study demonstrated that KFS-YE had an excellent narrow specificity against $Y$. enterocolitica only.

The broad $\mathrm{pH}$ and temperature stability of KFS-YE may be an advantageous characteristic because Yersinia in foods are exposed to various environmental conditions (Fig. 2). The FDA (2015) reported that the $\mathrm{pH}$ range of Yersinia growth was $4.2-10$ and the broad $\mathrm{pH}$ stability of KFS-YE

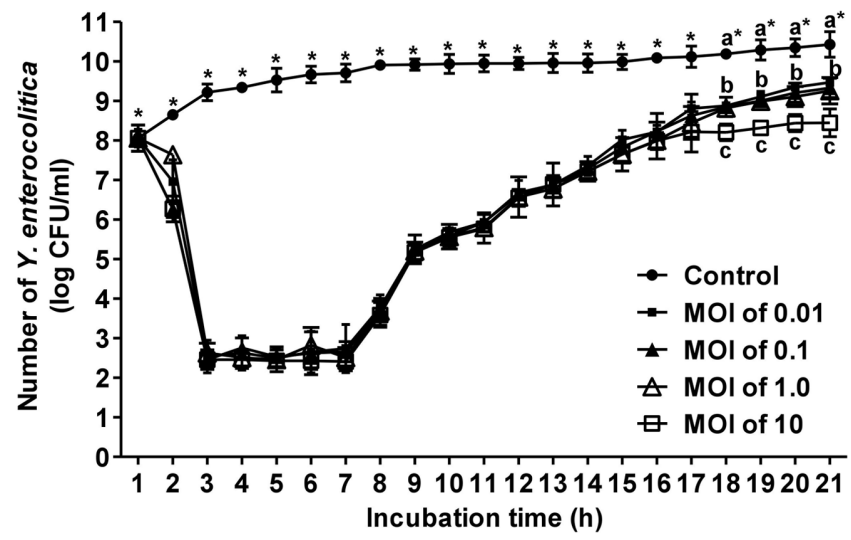

Fig. 4. Bactericidal effect of KFS-YE against Y. enterocolitica. Y. enterocolitica was infected by KFS-YE with MOIs of 0.01 ( $\mathbf{\square}), 0.1$ $(\Delta), 1.0(\triangle)$ or $10(\square)$. Control group was incubated without KFSYE inoculation ( ) . Asterisk $\left(^{*}\right)$ means that there is a significant difference between the control group and the infection group with KFS-YE at $p<0.05$. Different letters $(\mathrm{a}, \mathrm{b}$, and $\mathrm{c})$ after $17 \mathrm{~h}$ incubation time represent significant differences at $p<0.05$. 
( $\mathrm{pH} 4-11$ ) makes it suitable for its application. In addition, KFS-YE showed excellent stabilities at various temperatures between $4^{\circ} \mathrm{C}$ and $50^{\circ} \mathrm{C}$, and significantly weak stabilities at both $60^{\circ} \mathrm{C}$ and $70^{\circ} \mathrm{C}$. Interestingly, its robust stability at cold temperature $\left(4^{\circ} \mathrm{C}\right)$ could enhance its advantage as a biocontrol agent because of the psychrotrophic property of Y. enterocolitica. When compared with other studies reporting the temperature stabilities of the Klebsiella pneumoniaespecific phage [22] and Acinetobacter baumannii-specific phage [30] at $25-40^{\circ} \mathrm{C}$ and $50-60^{\circ} \mathrm{C}$, respectively, KFS-YE showed a relatively wide range of temperature stability. This suggests that the lytic activity of KFS-YE can occur both under relatively high as well as cold temperatures.

To guarantee phage quality, the phage needs to be sustained at its original quantity possessing viable status during certain storage periods. Although recent studies $[26,31]$ reported that phages can be inactivated or lost during storage presumably because of structural damage, lipid loss, and/or DNA structural changes, there have been very few studies performed regarding the storage stability of phages at different temperature conditions. As shown in Table 3, the overall trend of the KFS-YE titer declined very slightly with time such that the final phage titer was maintained in the range of $94-97 \%$ at $-20^{\circ} \mathrm{C}, 4^{\circ} \mathrm{C}$, and $22^{\circ} \mathrm{C}$ for 40 weeks. Unlike the findings of Capra et al. [32], wherein the Siphoviridae phage against Lactobacillus was more stable at $-20^{\circ} \mathrm{C}$ and $-80^{\circ} \mathrm{C}$ than at $4^{\circ} \mathrm{C}$, our phage was not stable at $-80^{\circ} \mathrm{C}$. Considering the economic issue, KFSYE showed robust stability for relatively long periods and this is further supportive of its practical use as a biocontrol agent.

Based on the one-step growth curve, the multiplication parameters of KFS-YE, such as the latent period and burst size, were analyzed (Fig. 3). The length of the latent period depends on the type of phage, phage species, physiological conditions, type of host, and the composition of the medium and incubation temperature [33]. The latent period of KFS-YE (45 min) was longer than those of both $\Phi Y e O 3-$ 12 (25 $\mathrm{min})$ and PY100 (30 min), whereas the burst size (38 PFU/cell) of KFS-YE was smaller than those of both ФYeO3-12 (120 PFU/cell) and PY100 (120 PFU/cell). Conversely, Jun et al. [34] showed a relatively shorter latent period (30 $\mathrm{min}$ ) and smaller burst size (16 PFU/cell) for the Shigella-specific phage as a new biocontrol agent. Since there have been no critical determinants for the latent period and burst size for its application as a biocontrol agent, these results showed that KFS-YE could lyse $Y$. enterocolitica effectively after a 45-min treatment with a burst size $38 \mathrm{PFU} /$ cell.

Furthermore, the bactericidal effect of KFS-YE against Y. enterocolitica was first investigated in this study (Fig. 4). As shown in Table 1, several phages have been reported, however, there have been no in vitro studies regarding the bactericidal effect of Yersinia-specific phages. The growth of $Y$. enterocolitica was decreased by KFS-YE and was sustained for $7 \mathrm{~h}$ even with MOI of 0.01 , although there were no obvious and significant differences observed among different dosages at the MOI values. Depending on the phage characteristic and property, the pattern of bactericidal effect will follow dose-dependent or doseindependent manners. The presumable reason for the doseindependent manner of KFS-YE was derived from a phageimmune system that is induced by phages for refusing other phage infection after its saturation [35]. In addition, the incomplete lysis of KFS-YE for $7 \mathrm{~h}$ at any MOIs could be explained by the possibility that some proportion of bacteria were able to show resistance to the phage or by the rapid appearance of resistant mutants [36]. Afterwards, regrowth of $Y$. enterocolitica was initiated, which agreed with previous studies using the SFP 10 phage against Salmonella enterica and E. coli O157:H7, and the FSP1 phage against Morganella morganii $[29,37]$. The reason for bacterial regrowth could be explained by the occurrence of spontaneous adaptation of the surviving bacteria during phage adsorption, phage DNA injection, cleavage of phage DNA, or abortive infection systems [9, 28, 37]. For the successful application of phages, this regrowth problem could be managed using phage cocktails rather than a single phage, and/or by increasing the MOI of the phages [37]. Although there are still many hurdles to address in the practical use of the KFS-YE phage, KFS-YE demonstrated excellent efficiency with the lowest MOI of 0.01. In addition, ORF analysis (data not provided) from whole genome sequencing of KFS-YE confirmed there were no toxin-related genes identified such as yst, ttcC, yadA, virF, ysa, and RTX-like toxins [38]. In future studies, KFS-YE will be directly employed to fresh produce for the reduction and prevention of $Y$. enterocolitica contamination for objective evaluation. In conclusion, this study demonstrated that KFS-YE was a potentially safe, effective, and promising biocontrol agent for the practical intervention of Y. enterocolitica in food.

\section{Acknowledgments}

This research was supported by the Rural Development Administration (RDA) of Korea, funded by the Cooperative 
Research Program for Agriculture Science and Technology Development (PJ012290).

\section{Conflict of Interest}

The authors have no financial conflicts of interest to declare.

\section{Reference}

1. Pajunen M, Kiljunen S, Skurnik M. 2000. Bacteriophage $\varphi \mathrm{YeO} 3-12$, specific for Yersinia enterocolitica serotype O: 3 , is related to coliphages T3 and T7. J. Bacteriol 182: 5114-5120.

2. Salem M, Virtanen S, Korkeala H, Skurnik M. 2015. Isolation and characterization of Yersinia-specific bacteriophages from pig stools in Finland. J. Appl. Microbiol. 118: 599-608.

3. Rahman A, Bonny TS, Stonsaovapak S, Ananchaipattana C. 2011. Yersinia enterocolitica: Epidemiological studies and outbreaks. J. Pathog. 2011: 239391.

4. Harris L, Farber J, Beuchat L, Parish M, Suslow T, Garrett E, et al. 2003. Outbreaks associated with fresh produce: incidence, growth, and survival of pathogens in fresh and fresh-cut produce. Compr. Rev. Food Sci. Food Saf. 2: 78-141.

5. MacDonald E, Einöder-Moreno M, Borgen K, Brandal LT, Diab L, Fossli, et al. 2016. National outbreak of Yersinia enterocolitica infections in military and civilian populations associated with consumption of mixed salad, Norway, 2014. Euro Surveill. 21. doi: 10.2807/1560-7917.

6. EFSA, 2012. The european union summary report on trends and sources of zoonoses, zoonotic agents and food-borne outbreaks in 2010. Euro Surveill 17: 2597.

7. Bottone EJ. 1997. Yersinia enterocolitica: the charisma continues. Clin. Microbiol. Rev. 10: 257-276.

8. Rashid MH, Revazishvili T, Dean T, Butani A, Verratti K, Bishop-Lilly KA, et al. 2012. A Yersinia pestis-specific, lytic phage preparation significantly reduces viable $Y$. pestis on various hard surfaces experimentally contaminated with the bacterium. Bacteriophage 2: 168-177.

9. Hwang S, Yun J, Kim KP, Heu S, Lee S, Ryu S. 2009. Isolation and characterization of bacteriophages specific for Campylobacter jejuni. Microbiol Immunol. 53: 559-566.

10. Park M-K, Oh J-H, Chin BA. 2011. The effect of incubation temperature on the binding of Salmonella typhimurium to phage-based magnetoelastic biosensors. Sens. Actuators B: Chem. 160: 1427-1433.

11. Byeon HM, Vodyanoy VJ, Oh J-H, Kwon J-H, Park M-K. 2015. Lytic phage-based magnetoelastic biosensors for onsite detection of methicillin-resistant Staphylococcus aureus on spinach leaves. J. Electrochem. Soc. 162: B230-B235.

12. Hudson J, Billington C, Carey-Smith G, Greening G. 2005. Bacteriophages as biocontrol agents in food. J. Food Prot. 68: 426-437.
13. Owens J, Barton MD, Heuzenroeder MW. 2013. The isolation and characterization of Campylobacter jejuni bacteriophages from free range and indoor poultry. Vet. Microbiol. 162: 144150 .

14. Choi IY, Lee J-H, Kim H-J, Park M-K. 2017. Isolation and characterization of a novel broad-host-range bacteriophage infecting Salmonella enterica subsp. enterica for biocontrol and rapid detection. J. Microbiol. Biotechnol. 27: 2151-2155.

15. Sharma M. 2013. Lytic bacteriophages. Bacteriophage 3: e25518.

16. Cox N, Berrang M, Cason J. 2000. Salmonella penetration of egg shells and proliferation in broiler hatching eggs--a review. Poult. Sci. 79: 1571-1574.

17. Oh J-H, Park M-K. 2017. Recent trends in Salmonella outbreaks and emerging technology for biocontrol of Salmonella using phages in foods: a review. J. Microbiol. Biotechnol. 27: 20752088.

18. Stevenson R, Airdrie D. 1984. Isolation of Yersinia ruckeri bacteriophages. Appl. Environ. Microbiol. 47: 1201-1205.

19. Popp A, Hertwig S, Lurz R, Appel B. 2000. Comparative study of temperate bacteriophages isolated from Yersinia. Syst. Appl. Microbiol. 23: 469-478.

20. Pujato SA, Guglielmotti DM, Ackermann H-W, Patrignani F, Lanciotti R, Reinheimer JA, et al. 2014. Leuconostoc bacteriophages from blue cheese manufacture: long-term survival, resistance to thermal treatments, high pressure homogenization and chemical biocides of industrial application. Int. J. Food Microbiol. 177: 81-88.

21. Park M-K, Wikle III HC, Chai Y, Horikawa S, Shen W, Chin BA. 2012. The effect of incubation time for Salmonella Typhimurium binding to phage-based magnetoelastic biosensors. Food Control. 26: 539-545.

22. Verma V, Harjai K, Chhibber S. 2009. Characterization of a T7-like lytic bacteriophage of Klebsiella pneumoniae B5055: a potential therapeutic agent. Curr. Microbiol. 59: 274-281.

23. Ackermann H-W, DuBow M, Jarvis A, Jones L, Krylov V, Maniloff J, et al. 1992. The species concept and its application to tailed phages. Arch. Virol. 124: 69-82.

24. Bradley DE. 1967. Ultrastructure of bacteriophage and bacteriocins. Bacteriol. Rev. 31: 230-314.

25. Puapermpoonsiri U, Ford S, Van der Walle C. 2010. Stabilization of bacteriophage during freeze drying. Int. J. Pharm. 389: 168-175.

26. Golec P, Dąbrowski K, Hejnowicz MS, Gozdek A, Łoś JM, Wegrzyn $G$, et al. 2011. A reliable method for storage of tailed phages. J. Microbiol. Methods 84: 486-489.

27. Li L, Zhang Z. 2014. Isolation and characterization of a virulent bacteriophage SPW specific for Staphylococcus aureus isolated from bovine mastitis of lactating dairy cattle. Mol. Biol. Rep. 41: 5829-5838.

28. Haq IU, Chaudhry WN, Andleeb S, Qadri I. 2012. Isolation and partial characterization of a virulent bacteriophage IHQ1 specific for Aeromonas punctata from stream water. Microb. Ecol. 63: 954-963. 
29. Park M, Lee J-H, Shin H, Kim M, Choi J, Kang D-H, et al. 2012. Characterization and comparative genomic analysis of a novel bacteriophage SFP10 simultaneously inhibiting both Salmonella and Escherichia coli O157: H7. Appl. Environ. Microbiol. 78: 58-69.

30. Yang H, Liang L, Lin S, Jia S. 2010. Isolation and characterization of a virulent bacteriophage AB1 of Acinetobacter baumannii. BMC Microbiol. 10: 131.

31. Ackermann H-W, Tremblay D, Moineau S. 2004. Long-term bacteriophage preservation. WFCC Newslett. 38: 35-40.

32. Capra M, Quiberoni AdL, Ackermann H-W, Moineau S, Reinheimer J. 2006. Characterization of a new virulent phage (MLC-A) of Lactobacillus paracasei. J. Dairy Sci. 89: 2414-2423.

33. Weinbauer MG. 2004. Ecology of prokaryotic viruses. FEMS Microbiol. Rev. 28: 127-181.

34. Jun JW, Kim HJ, Yun SK, Chai JY, Lee BC, Park SC. 2016. Isolation and comparative genomic analysis of T1-like Shigella bacteriophage pSf-2. Curr. Microbiol. 72: 235-241.

35. Shen G-H, Wang J-L, Wen F-S, Chang K-M, Kuo C-F, Lin C-H, et al. 2012. Isolation and characterization of $\varphi \mathrm{km} 18 \mathrm{p}$, a novel lytic phage with therapeutic potential against extensively drug resistant Acinetobacter baumannii. PLoS One 7: e46537.

36. Kim M, Ryu S. 2011. Characterization of a T5-like coliphage
SPC35 and differential development of resistance to SPC35 in Salmonella Typhimurium and Escherichia coli. Appl. Environ. Microbiol. 77: 2041-2050.

37. Yamaki S, Omachi T, Kawai Y, Yamazaki K. 2014. Characterization of a novel Morganella morganii bacteriophage FSP1 isolated from river water. FEMS Microbiol. Lett. 359: 166-172.

38. Gnanasekaran G, Na EJ, Chung HY, Kim S, Kim Y-T, Kwak W, et al. 2017. Genomic isights and its comparative analysis with Yersinia enterocolitica reveals the potential virulence determinants and further pathogenicity for foodborne outbreaks. J. Microbiol. Biotechnol. 27: 262-270.

39. Kasatiya S, Ackermann H-W. 1986. Morphology of Yersinia enterocolitica phages. Ann. Inst. Pasteur. Virol. 137: 59-69.

40. Schwudke D, Ergin A, Michael K, Volkmar S, Appel B, Knabner D, et al. 2008. Broad-host-range Yersinia phage PY100: genome sequence, proteome analysis of virions, and DNA packaging strategy. J. Bacteriol. 190: 332-342.

41. Leon-Velarde CG, Kropinski AM, Chen S, Abbasifar A, Griffiths MW, Odumeru JA. 2014. Complete genome sequence of bacteriophage vB_YenP_AP5 which infects Yersinia enterocolitica of serotype O: 3. Virol. J. 11: 188. 